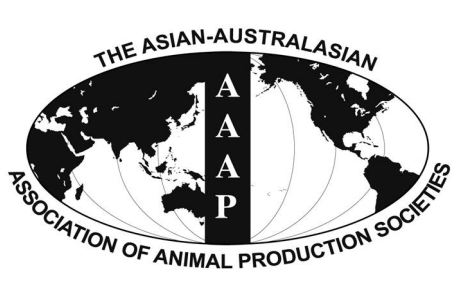

Open Access

Asian Australas. J. Anim. Sci.

Vol. 28, No. 11 : 1573-1582 November 2015

http://dx.doi.org/10.5713/ajas.15.0185

Www.ajas.info

pISSN 1011-2367 elSSN 1976-5517

\title{
Effect of Soyabean Isoflavones Exposure on Onset of Puberty, Serum Hormone Concentration and Gene Expression in Hypothalamus, Pituitary Gland and Ovary of Female Bama Miniature Pigs
}

\author{
Juexin Fan ${ }^{1,2}$, Bin Zhang ${ }^{1, *}$, Lili Li ${ }^{2}, *$, Chaowu Xiao ${ }^{3}$, Oso Abimbola Oladele ${ }^{4}$, Guoli Jiang ${ }^{2}$, \\ Hao Ding ${ }^{1,2}$, Shengping Wang $^{2}$, Yueteng Xing ${ }^{1,2}$, Dingfu Xiao ${ }^{1}$, and Yulong Yin ${ }^{2}$ \\ ${ }^{1}$ College of Animal Science and Technology, Hunan Agricultural University, Changsha 410128, China
}

\begin{abstract}
This study was to investigate the effect of soyabean isoflavones (SIF) on onset of puberty, serum hormone concentration, and gene expression in hypothalamus, pituitary and ovary of female Bama miniature pigs. Fifty five, 35-days old pigs were randomly assigned into 5 treatment groups consisting of 11 pigs per treatment. Results showed that dietary supplementation of varying dosage $(0,250,500$, and $1,250 \mathrm{mg} / \mathrm{kg})$ of SIF induced puberty delay of the pigs with the age of puberty of pigs fed basal diet supplemented with $1,250 \mathrm{mg} / \mathrm{kg}$ SIF was significantly higher $(\mathrm{p}<0.05)$ compared to control. Supplementation of SIF or estradiol valerate $(E V)$ reduced $(p<0.05)$ serum gonadotrophin releasing hormone and luteinizing hormone concentration, but increased folliclestimulating hormone concentration in pigs at 4 months of age. The expression of KiSS-1 metastasis-suppressor (KISS1), steroidogenic acute regulatory protein (StAR) and 3-beta-hydroxysteroid dehydrogenase/delta-5-delta-4 isomerase $(3 \beta$-HSD) was reduced ( $<0.01)$ in SIF-supplemented groups. Expression of gonadotropin-releasing hormone receptor in the pituitary of miniature pigs was reduced $(\mathrm{p}<0.05)$ compared to the control when exposed to $250,1,250 \mathrm{mg} / \mathrm{kg} \mathrm{SIF}$ and EV. Pigs on $250 \mathrm{mg} / \mathrm{kg}$ SIF and EV also showed reduced $(\mathrm{p}<0.05)$ expression of cytochrome P450 19A1 compared to the control. Our results indicated that dietary supplementation of SIF induced puberty delay, which may be due to down-regulation of key genes that play vital roles in the synthesis of steroid hormones. (Key Words: Soybean Isoflavones, Puberty, Puberty Delay, Bama Miniature Pigs)
\end{abstract}

\section{INTRODUCTION}

Isoflavones are the major class of phytoestrogens

\footnotetext{
* Corresponding Authors: Bin Zhang. Tel: +86-731-84618088, Fax: +86-731-84610280, E-mail: zhb8236@126.com / Lili Li. Tel: +86731-8461-9705, Fax: +86-731-8461-2685, E-mail: 1ili@isa.ac.cn

${ }^{2}$ Scientific Observing and Experimental Station of Animal Nutrition and Feed Science in South-Central, Ministry of Agriculture, Hunan Provincial Engineering Research Center of Healthy Livestock, Key Laboratory for Agro-Ecological Processes of Subtropical Region, Institute of Subtropical Agriculture, The Chinese Academy of Sciences, Changsha, 410125, China.

${ }^{3}$ Nutrition Research Division, Food Directorate, Health Canada, Ottawa, Ontario, K1A 0K9, Canada.

${ }^{4}$ Department of Animal Nutrition, College of Animal Science and Livestock Production, Federal University of Agriculture, Abeokuta, PMB2240, Nigeria.

Submitted Mar. 4, 2015; Revised May 8, 2015; Accepted Jun. 11, 2015
}

contained mostly in soybean (Jefferson and Williams, 2011). Daidzein and genistein are the main types of soybean isoflavones (SIF), which preferentially bind to estrogen receptor (Setchell et al., 1998), induce growth arrest, apoptosis and exert hormone-like effects through a nonhormonal mechanism by inhibiting tyrosine kinases (Yan et al., 2010).

Previous studies have shown conflicting reports on the effect of SIF. One school of thought suggested that exposure to estrogenic substances during critical periods can pose adverse consequences on the reproductive physiology (Dickerson and Gore, 2007) and leads to fertility problems in animals (Jefferson et al., 2005). Adverse effects like altered estrous cyclicity, altered ovulation, subfertility, and infertility have been reported on the female reproductive system (Jefferson and Williams, 2011). Several forms of estrogen-related toxicity was 
reported in experimental animals exposed to SIF (Doerge and Sheehan, 2002). However, beneficial effects of SIF have also been suggested (Strom et al., 2001). Currently, there is debate regarding the physiological impact of SIF consumption and whether or not it warrants concern.

The mechanism underlining the onset of premature puberty is controlled by a system of positive and negative feedback of the reproductive hormones that are produced and released through hypothalamus-pituitary-ovaries axis (Soede et al., 2011). Kisspeptin-G protein-coupled receptor (GPR54) signaling is considered to play an important role in pubertal onset in many mammal species, and many KiSS-1 metastasis-suppressor (KISS1)-expressing cells were observed in the ARC (Hypothalamic arcuate nuclei) of the pig hypothalamus throughout the developing period (Nahoko Ieda et al., 2014). Previous research studies showed that mutations in KISS1R were associated with impaired pubertal maturation (Oakley et al., 2009). Genistein was reported to suppress Gonadotrophin releasing hormone (GnRH) activation, decrease the KISS immunolabeled and immunoreactive fibers in the anteroventral periventricular nucleus (AVPV) of hypothalamus when neonatal rats were exposure to phytoestrogens (Bateman and Patisual, 2008; Losa et al., 2011). GnRH from the hypothalamus stimulates the anterior pituitary to secrete follicle-stimulating hormone (FSH) and luteinizing hormone (LH), which act on the ovary to promote folliculogenesis and the concomitant synthesis of estradiol. Meanwhile, estradiol is considered the critical determinant of plasma gonadotropin levels in the female by completing an endocrine feedback loop upon the hypothalamus to reduce GnRH secretion.

Soybean and its products have been considered as an outstanding source of supplemental protein in ration for swine (Li et al., 1991) because of its constituent superior blend of amino acids which are needed as building blocks of body protein. Increased fertility in swine has been recognized as one of the most important factor towards increased global swine production. Sterle and Lamberson (1996) corroborated the fact that a decrease in the age of attainment of puberty by pigs will result in concomitant reduction in the resultant costs of swine production. However, it is not clear whether pubertal exposure to phytoestrogens affects reproductive function during adulthood (Dickerson and Gore, 2007), and there is no report which focused on their effects on puberty of pigs. Bama miniature pig was used as experimental model in the study because it is easy to handle, reduced cost, genetic adaptability, stable heredity and production performance ( Ju et al., 2014). This research study was designed with the hypothesis that SIF exposure in developing pigs may influence hormone regulation in the hypothalamus- pituitary-ovary axis and consequently the onset of puberty of pigs.

\section{MATERIALS AND METHODS}

\section{Animals}

A total of fifty five (55), 35-days old Bama miniature pigs with average weight $2.80 \pm 1.0 \mathrm{~kg}$ were obtained from a local pig herd in Bama County, a South-west county of China and used for this experiment. Pigs used in this study were selected from a total of eleven (11) farrowing mothers amidst the herd. Five healthy female pigs were selected from each mother and randomly assigned into five treatment groups. Thus, there were a total of eleven pigs per treatment.

\section{Dietary treatments and management}

The standard basal diet designated as control was formulated to meet the nutrient requirement and physiological needs of growing (stage 1) and gestation (stage 2) Bama miniature pigs. Four experimental diets were subsequently formulated by supplementing the basal diet with $0,250,500$, and 1,250 $\mathrm{mg} / \mathrm{kg}$ SIF ( $80 \%$ purity), respectively. An additional fifth treatment designated as positive control was formulated to include $0.66 \mathrm{mg} / \mathrm{kg}$ estradiol valerate (EV, Equivalent to $0.5 \mathrm{mg} / \mathrm{kg}$ estradiol). Pigs were fed these diets from the beginning of the experiment till slaughter. The doses of SIF were determined due to our previous study which showed reduced serum LH concentration following dietary inclusion of $500 \mathrm{mg} / \mathrm{kg} \mathrm{SIF}$ in boars (Yuan et al., 2012). Basal diets fed to gilts at two stages are presented in Table 1. The SIF (Xi' An Rongsheng Biotechnology Co. Ltd., Xi' an, China) and EV (Delpharm Lille SAS, Lys-Lez-Lannoy, France) were obtained commercially and supplemented in the experimental diets by mixing thoroughly at the point of feeding. The concentration of daidzin in the SIF product was 52.19\%, while the glycitin, genistin, dai dzein, glycitein and genistein was $31.65 \%, 12.09 \%, 1.54 \%, 0.40 \%$, and $0.13 \%$, respectively. Pigs were fed twice (at 8:00 am and 17:00 pm) on a daily basis at $3 \%$ of their body weight. Water was offered ad libitum to the animals. Pigs were housed individually with hard plastic slatted floor, separate feeder and water trough. This study was conducted in accordance with the Chinese guidelines for animal welfare while the experimental protocol was approved by the Animal Care and Use Committee of The Chinese Academy of Sciences (Yin et al., 2004).

\section{Estrous detection}

The period of estrus was determined by assessment of estrous behavior, in which pressure was applied manually to the sow's back in the presence of the boar. Females that 
Table 1. Composition of experimental diets fed to pigs in stage 1 (d 35 to $\mathrm{d} 95$ ) and stage 2 (d 96 to farrow)

\begin{tabular}{lcc}
\hline \multirow{2}{*}{ Items } & \multicolumn{2}{c}{ Diets } \\
\cline { 2 - 3 } & Stage $1^{\mathrm{a}}$ & Stage $2^{\mathrm{b}}$ \\
\hline Ingredient (\%) & & \\
Corn & 41.49 & 40 \\
Wheat bran & 20 & 24 \\
Wheat middlings & 15 & 11.85 \\
Rice bran & 10 & 12 \\
Fish meal & 6 & - \\
Rapeseed meal & 3 & 3 \\
Corn gluten meal & 2 & - \\
Rice protein powder & - & 4.73 \\
Limestone & 0.77 & 1.968 \\
Dicalcium phosphate & 0.24 & 1.072 \\
Lysine & 0.28 & 0.09 \\
Salt & 0.15 & 0.208 \\
Choline & 0.08 & 0.08 \\
Premix & 1 & 1 \\
Total & 100 & 100 \\
Calculated composition $(\%)$ & & \\
DE (kcal/kg) & 2,982 & 2,900 \\
CP & 15.5 & 14.5 \\
Lys & 0.88 & 0.6 \\
Met + Cys & 0.549 & 0.403 \\
Ca & 0.74 & 1 \\
TP & 0.79 & 0.3 \\
AP & 0.35 & \\
\hline DE, & & \\
\hline
\end{tabular}

$\mathrm{DE}$, digestible energy; $\mathrm{CP}$, crude protein; $\mathrm{TP}$, total phosphrous; $\mathrm{AP}$, apparent phosphrous.

${ }^{\mathrm{a}}$ Diet of stage 1 supplied per kilogram of diet: $\mathrm{Cu}, 4.54 \mathrm{mg}$; Fe, $90.9 \mathrm{mg}$; Mn, $3 \mathrm{mg}$; Zn, $90.9 \mathrm{mg}$; I, $0.12 \mathrm{mg}$; Se, $0.26 \mathrm{mg}$; vitamin A, 65,000 IU; vitamin $\mathrm{D}, 18,750 \mathrm{IU}$; vitamin $\mathrm{E}, 175 \mathrm{IU}$; vitamin $\mathrm{K}_{3}, 25 \mathrm{mg}$; vitamin $\mathrm{B}_{1}$, $25 \mathrm{mg}$; riboflavin, $55 \mathrm{mg}$; vitamin $\mathrm{B}_{6}, 30 \mathrm{mg}$; vitamin $\mathrm{B}_{12}, 0.19 \mathrm{mg}$; niacin, $250 \mathrm{mg}$; folic acid, $10 \mathrm{mg}$; calcium pantothenate, $125 \mathrm{mg}$; biotin, $1 \mathrm{mg}$.

${ }^{\mathrm{b}}$ Diet of stage 2 supplied per kilogram of diet: $\mathrm{Cu}, 4.2 \mathrm{mg}$; Fe, $73.5 \mathrm{mg}$; Mn, $16.8 \mathrm{mg}$; Zn, $52.5 \mathrm{mg}$; I, $0.13 \mathrm{mg}$; Se, $0.16 \mathrm{mg}$; vitamin A, 70,000 IU; vitamin D, 21,250 IU; vitamin E, $0.3 \mathrm{~g}$; vitamin $\mathrm{K}_{3}, 25 \mathrm{mg}$; vitamin $\mathrm{B}_{1}, 25 \mathrm{mg}$; riboflavin, $55 \mathrm{mg}$; vitamin $\mathrm{B}_{6}, 35 \mathrm{mg}$; vitamin $\mathrm{B}_{12}, 0.25 \mathrm{mg}$; niacin, $300 \mathrm{mg}$; folic acid, $30 \mathrm{mg}$; calcium pantothenate, $125 \mathrm{mg}$; biotin, $2.25 \mathrm{mg}$.

showed a 'standing estrous reflex' were considered to be in estrus (Tomikawa et al., 2010). The Bama miniature pigs usually reach puberty at 120 to 140 day. After 60 day of feeding, all pigs were checked twice every day in the presence of a mature boar until the standing estrous reflex was observed. The day when females showed standing estrous reflex was set as the age of puberty. Effects of SIF on the onset of puberty was estimated by expressing the number of pigs which showed signs of estrous as a percentage of the total number of pigs contained in each treatment group.

\section{Serum sample collection and analysis of serum hormone concentration}

Blood samples ( $\mathrm{n}=6$ per treatments) were collected from the pigs at 4 month of age, the second and the fourth day of estrus. Blood samples were collected in the morning after 12 hours fasting of the pigs through jugular venipuncture and stored at $4^{\circ} \mathrm{C}$ for 6 hours in heparinised tubes. The blood were subsequently centrifuged at $1,000 \times \mathrm{g}$ for 10 minutes, and the supernatant were collected and stored at $-20^{\circ} \mathrm{C}$ for subsequent analysis. $\mathrm{GnRH}, \mathrm{LH}$, estradiol $\left(\mathrm{E}_{2}\right)$ and progesterone $\left(\mathrm{P}_{4}\right)$ levels in the serum were measured using ELISA kits (Cusabio Biotech Co. Ltd., Wuhan, China) with the intra-assay (coefficient of variation $[\mathrm{CV}]<15 \%)$ and inter-assay $(\mathrm{CV}<15 \%)$ precision. The FSH in the serum was measured using enzyme-linked immunosorbent assay kit (R\&D Systems China, Shanghai, China) with the intra-assay $(\mathrm{CV}<9 \%)$ and inter-assay $(\mathrm{CV}<11 \%)$ precision.

\section{Preparation of tissues}

The exact day that the pigs contained in each treatment showed standing estrous reflex was defined as the first day of estrus. At the fourth day of estrous, pigs were slaughtered in the morning. The hypothalamus, pituitary and right ovary were immediately separated and were frozen quickly in liquid nitrogen, and then stored at $-80^{\circ} \mathrm{C}$ for subsequent analysis.

\section{Semi-quantitative polymerase chain reaction (RT-PCR) analysis}

Total RNA was extracted using TRizol reagent (Invitrogen, Carlsbad, CA, USA) and treated with DNase. Reverse transcription was performed using PrimeScript RT reagent Kit with gDNA eraser (Takara, Dalian, China) according to the manufacturer's instruction. The primer pairs for the genes are presented in Table 2. Beta-2microglobulin was used as the housekeeping gene, whose mRNA levels in the hypothalamus, pituitary and ovary did not differ among the groups. Primers provided by Sangon Biotech Co. Ltd. (Shanghai, China) were used. Before realtime polymerase chain reaction (RT-PCR) procedure, all designed primers were tested using a PCR program with the complementary DNA and the products size were correct. RT-PCR was carried out in a $10 \mu \mathrm{L}$ volume by Thermo Scientific DyNAmo Flash SYBR Green qPCR Kit (Thermo Fisher Scientific Inc., Waltham, CT, USA), ABI PRISM 7900HT Fast Real-time PCR system (Applied Biosystems, Waltham, CT, USA). The RT-PCR conditions were; 7 minutes pre-denaturation at $95^{\circ} \mathrm{C}$, and then 15 seconds denaturation at $95^{\circ} \mathrm{C}$, and 30 seconds annealing at $60^{\circ} \mathrm{C}$ for 40 cycles. After PCR, melting curves were obtained by stepwise increases in temperature from $60^{\circ} \mathrm{C}$ to $95^{\circ} \mathrm{C}$. The relative quantification of gene amplification was performed 
Table 2. Primer sequences and accession number used for measurements of selected genes using RT-PCR

\begin{tabular}{|c|c|c|c|}
\hline Genes & Accession No. & Nucleotide sequence & Product length (bp) \\
\hline \multirow[t]{2}{*}{$B 2 M$} & NM_213978.1 & F: TTTCTACCTTCTGGTCCACACTG & 102 \\
\hline & & R: CACTTAACTATCTTGGGCTTATCG & \\
\hline \multirow[t]{2}{*}{ KISS1 } & NM_001134964.1 & F: GGACCTCATCGTGCCAGCCT & 152 \\
\hline & & R: GCCGAAGGAGTTCCAGTTGTAGG & \\
\hline \multirow[t]{2}{*}{ GPR54 } & DQ459346.1 & F: CGTGCCCTTTACTGCTCTACTC & 160 \\
\hline & & R: CAGCGGAAACACAGTCACATAC & \\
\hline \multirow[t]{2}{*}{ GNRH1 } & NM_214274.1 & F: GAGCCAATTCCGAAACTTCTAGC & 267 \\
\hline & & R: CTTCTGCCCAGTTTCCTCTTCA & \\
\hline \multirow[t]{2}{*}{ GNRHR } & NM_214273.1 & F: CTTCCCACCCTGACCTTATCT & 121 \\
\hline & & R: CTTTCCTTTGAGTCCATTTCTG & \\
\hline \multirow[t]{2}{*}{$F S H \beta$} & NM_213875.1 & F: CCCATCTCCCAATCTGTCTCA & 162 \\
\hline & & R: CCCATTCTTAGCCCATTTCCT & \\
\hline \multirow[t]{2}{*}{$L H \beta$} & NM_214080.1 & F: TGTTGTGGCTGCTGCTGAG & 137 \\
\hline & & R: GATGCTGGTGGTAAAGGTGATG & \\
\hline \multirow[t]{2}{*}{ StAR } & NM_213755.2 & F: GACGGATGGAAGGGATAGTTG & 228 \\
\hline & & R: CCCACATTCCTGCTATTGCTAA & \\
\hline \multirow[t]{2}{*}{$3 \beta-H S D$} & NM_001004049.1 & F: CCTTCAATCGCCACTTCG & 220 \\
\hline & & R: TCCCCTCACACCCACATC & \\
\hline \multirow[t]{2}{*}{ CYP11A1 } & NM_214427.1 & F: GCTCGGCAACTTGGAATCT & 98 \\
\hline & & R: GCGGGATGTTGTATCGTTCT & \\
\hline \multirow[t]{2}{*}{ CYP17A1 } & NM_214428.1 & F: AGAACTACAGCAGAAACTCCATCA & 186 \\
\hline & & R: TCCACTTTACCACAGAGGCAG & \\
\hline \multirow[t]{2}{*}{ CYP19A1 } & NM_214429.1 & F: GAGGAGGTCCGCAATGACTT & 88 \\
\hline & & R: CCAGGAAGAGGTTGTTAGAGGTG & \\
\hline \multirow[t]{2}{*}{ FSHR } & NM_214386.2 & F: ACTGGAGGCGGCAAATCT & 133 \\
\hline & & R: TTGGCTAAACTGGACTCACCA & \\
\hline \multirow[t]{2}{*}{$L H R$} & NM_214449.1 & F: CAAGGAGACCAAATAATGAAACAC & 326 \\
\hline & & R: GGCAATGAGTAGCAGGTAGAGC & \\
\hline
\end{tabular}

RT-PCR, real-time polymerase chain reaction; B2M, beta-2-microglobulin; KISS1, KiSS-1 metastasis-suppressor; GPR54, G protein-coupled receptor 54; GNRH1, gonadotropin-releasing hormone 1; GNRHR, gonadotropin-releasing hormone receptor; FSH $\beta$, follicle stimulating hormone, beta polypeptide; LH $\beta$, luteinizing hormone-beta; StAR, steroidogenic acute regulatory protein; 3 $\beta$-HSD, 3-beta-hydroxysteroid dehydrogenase/delta-5-delta-4 isomerase; CYP11A1, cytochrome P450, family 11, subfamily A, polypeptide 1; CYP17A1, cytochrome P450 17A1; CYP19A1, cytochrome P450 19A1; FSHR, follicle stimulating hormone receptor; LHR, luteinizing hormone/choriogonadotropin receptor.

using cycle threshold $(\mathrm{Ct})$ values. Then the expression level of each gene conducted by the comparative $\mathrm{Ct}$ value method was expressed as described by Fu et al. (2006).

\section{Western blot analysis}

The ovaries were made into powder in liquid nitrogen. About $100 \mathrm{mg}$ sample was transferred into $1.5 \mathrm{~mL}$ microcentrifuge tube containing ice-cold RIPA buffer (Beyotime Institute of Biotechnology, Beijing, China) and a cocktail of Phosphatase Inhibitor Cocktail Tablets, Protease Inhibitor Cocktail Tablets (Roche Diagnostics Ltd., Shanghai, China) according to their manuscript, and mixed thoroughly. The mixture was stored at $4^{\circ} \mathrm{C}$ for 1 hour and then centrifuged at $13,000 \times \mathrm{g}$ for 10 minutes at $4^{\circ} \mathrm{C}$ and the supernatant was carefully transferred to another microtube. Protein concentration was estimated by the Enhanced BCA Protein Assay Kit (Beyotime Insititute of Biotechnology, China).
The samples were treated at $99^{\circ} \mathrm{C}$ for 7 minutes and 10 $\mu \mathrm{L}$ of the sample was subjected to $10 \%$ SDS-PAGE (Beyotime Insititute of Biotechnology, China) at $60 \mathrm{~V}$ for 40 minutes and then at $120 \mathrm{~V}$ for 1 hour. After electrophoresis, proteins were transferred to PVDF membrane (Merck KGaA, Darmstadt, Germany), which was then blocked for 1 hour in Tris-buffered saline plus $0.2 \%$ Tween 20 (TBST) plus 5\% nonfat dry milk. Membranes were subsequently incubated at room temperature for 3 hour with diluted antibodies diluted as follows: anti-steroidogenic acute regulatory protein (StAR, 1:200), anti-3 $\beta$-hydroxysteroid dehydrogenase/delta-5-delta-4 isomerase (HSD, 1:200) and anti-CYP19 (1:200) or anti- $\beta$-actin (1:2000) (Santa Cruz Biotechnology, Santa Cruz, CA, USA) in TBST. After four 5 minutes washes with TBST, the membranes were incubated with diluted secondary antibodies (1:4000) at room temperature for 1 hour. After four 5 minutes washes with TBST, specific signals were detected by using ECL 
reagent (Beyotime Insititute of Biotechnology, China) and visualized by Gel-Pro analyzer.

\section{Statistical analysis}

Results are presented as mean \pm standard error of the mean. Data were arranged in a completely randomised design and analysed using IBM SPSS version 21.0 (IBM Co., Armonk, NY, USA). Analysis of variance was performed to evaluate the differences between mean values followed by Duncan post hoc test to determine the effects of treatments (Control, SIF-250, SIF-500, SIF-1250, and EV$0.66)$. Probability values of $5 \%$ level of significance $(p<0.05)$ were used to detect significant levels. Descriptive representations of gene expressions in hypothalamus, pituitary, and ovary were done with the aid of bar chart.

\section{RESULTS}

\section{Estrus ratio and age of puberty}

The number of female Bama miniature pigs which showed estrous reflex at different ages following SIF exposure were shown in Table 3. At all various ages, control group had the highest numerical number of miniature pigs which showed estrous reflex. At 150 days of age, only 1 pig showed estrous reflex in SIF-250, SIF-500, and EV, and no pig showed estrous reflex in SIF-1250 at 150 and 180 days of age. At 210 days, all the pigs in control (100\%) already reached puberty while only 4 pigs in SIF-250 (44.4\%), 5 pigs in SIF-500 (50\%), 2 pigs in SIF-1250 (20\%) and 6 pigs in group EV (54.5\%) showed estrous reflex. Only 55.6\% (5 out of 9 ), $70 \%$ ( 7 out of 10 ), $60 \%$ (6 out of 10 ), and $72.7 \%$ (8 out of 11) of pigs in group SIF-250, SIF-500, SIF-1250 and $\mathrm{EV}$, respectively showed estrous reflex at the last day of the study (240 day). In the meanwhile, the age of puberty of female Bama miniature pigs fed basal diet supplemented with $1,250 \mathrm{mg} / \mathrm{kg}$ SIF was significantly higher $(\mathrm{p}<0.05)$ compared to control (Table 4). These suggested that dietary supplementation with SIF induced puberty delay of Bama miniature pigs.

\section{Serum hormone concentration}

The serum hormone concentration of Bama miniature pigs was shown in Table 5. At 4 months old, the $E_{2}$ concentration of the Bama miniature pigs did not differ $(p>0.05)$ in all treatment when compared to the control. The serum GnRH, LH concentration of pigs fed basal diets supplemented with varying dosage of SIF and EV were
Table 3. Effects of soybean isoflavones on estrus ratio of female Bama miniature pigs

\begin{tabular}{cccccc}
\hline $\begin{array}{c}\text { Age } \\
(\mathrm{d})\end{array}$ & $\begin{array}{c}\text { Control } \\
(\mathrm{n}=11)\end{array}$ & $\begin{array}{c}\text { SIF 250 } \\
(\mathrm{n}=9)\end{array}$ & $\begin{array}{c}\text { SIF 500 } \\
(\mathrm{n}=10)\end{array}$ & $\begin{array}{c}\text { SIF 1250 } \\
(\mathrm{n}=10)\end{array}$ & $\begin{array}{c}\text { EV 0.66 } \\
(\mathrm{n}=11)\end{array}$ \\
\hline 150 & $5(45)^{\mathrm{a}}$ & $1(11)$ & $1(10)$ & 0 & $1(9)$ \\
180 & $7(63.6)$ & $3(33.3)$ & $4(40)$ & 0 & $3(27.3)$ \\
210 & $11(100)$ & $4(44.4)$ & $5(50)$ & $2(20)$ & $6(54.5)$ \\
240 & $11(100)$ & $5(55.6)$ & $7(70)$ & $6(60)$ & $8(72.7)$ \\
\hline
\end{tabular}

SIF, soyabean isoflavones; $\mathrm{EV}$, estradiol valerate.

Values are expressed as ratio of the number of pigs which showed estrous reflex to total number of survived pigs per treatment $(\%)$.

significantly reduced $(\mathrm{p}<0.05)$, while the FSH of pigs in group of SIF-500, SIF-1250, and EV were higher $(p<0.05)$ than values obtained from the pigs in control. The serum concentration of $\mathrm{P}_{4}$ of pigs fed basal diet with $250 \mathrm{mg} / \mathrm{kg}$ SIF was reduced $(\mathrm{p}<0.05)$ compared to control.

At the second day of estrus, the serum GnRH concentration was reduced $(\mathrm{p}<0.05)$ following dietary supplementation with $250,500 \mathrm{mg} / \mathrm{kg}$ SIF and $0.66 \mathrm{mg} / \mathrm{kg}$ $\mathrm{EV}$, and serum $\mathrm{P}_{4}$ concentration was reduced $(\mathrm{p}<0.05)$ following dietary supplementation with $250 \mathrm{mg} / \mathrm{kg}$ SIF. At the fourth day of estrus, dietary supplementation with 500 $\mathrm{mg} / \mathrm{kg}$ SIF and $0.66 \mathrm{mg} / \mathrm{kg}$ decreased $(\mathrm{p}<0.05)$ the serum $\mathrm{GnRH}$ and $\mathrm{P}_{4}$ concentration, and serum LH concentration was reduced $(\mathrm{p}<0.05)$ following dietary supplementation with $500,1,250 \mathrm{mg} / \mathrm{kg}$ SIF and $0.66 \mathrm{mg} / \mathrm{kg} \mathrm{EV}$. These indicated that dietary supplementation with SIF induced decrease of hormones which play essential roles on onset of puberty of pigs.

\section{KISS1, GPR54, and GNRH1 gene expression}

The gene expression of KISS1 gene in the hypothalamus of Bama miniature pigs reduced significantly $(p<0.05)$ following dietary supplementation with varying dosage of soy isoflavone and $0.66 \mathrm{mg} / \mathrm{kg}$ estradiol in the present study (Figure 1). However, the GPR54 and gonadotropinreleasing hormone 1 (GNRH1) gene expression were not influenced $(\mathrm{p}>0.05)$ following dietary supplementation with varying dosage of soy isoflavone and $0.66 \mathrm{mg} / \mathrm{kg}$ estradiol. These suggested that KISS1 may be more sensitive to the SIF exposure of the Bama miniature pigs.

\section{GnRHR, FSH $\beta$, and $L H \beta$ gene expression}

The expression of gonadotropin-releasing hormone receptor $($ GNRHR) reduced significantly $(\mathrm{p}<0.05)$ in pigs from SIF-250, SIF-1250, and EV when compared to those

Table 4. Effects of soybean isoflavones on age of puberty of Bama miniature pigs

\begin{tabular}{lccccc}
\hline Variable & Control & SIF-250 & SIF-500 & SIF-1250 & EV-0.66 \\
\hline Gilts numbers & 11 & 5 & 7 & 6 & 8 \\
Age of puberty (d) & $169.00 \pm 8.01^{\mathrm{a}}$ & $182.60 \pm 17.96^{\mathrm{a}, \mathrm{b}}$ & $182.86 \pm 13.66^{\mathrm{a}, \mathrm{b}}$ & $212.00 \pm 5.90^{\mathrm{b}}$ & $188.25 \pm 11.34^{\mathrm{a}, \mathrm{b}}$ \\
\hline
\end{tabular}

SIF, soyabean isoflavones; EV, estradiol valerate.

${ }^{a, b}$ Letters on the same row with different superscripts differs significantly $(p<0.05)$. 
Table 5. Serum hormone concentration of the pigs following treatment of SIF and EV

\begin{tabular}{|c|c|c|c|c|c|}
\hline Variable & Control & SIF-250 & SIF-500 & SIF-1250 & EV-0.66 \\
\hline \multicolumn{6}{|l|}{4 mo of age } \\
\hline $\mathrm{GnRH}(\mathrm{pg} / \mathrm{mL})$ & $18.74 \pm 3.44^{\mathrm{a}}$ & $11.84 \pm 1.14^{\mathrm{b}}$ & $10.36 \pm 2.07^{\mathrm{b}}$ & $7.06 \pm 1.86^{\mathrm{b}}$ & $7.72 \pm 1.30^{\mathrm{b}}$ \\
\hline $\mathrm{E}_{2}(\mathrm{pg} / \mathrm{mL})$ & $97.79 \pm 9.37^{\mathrm{a}, \mathrm{b}}$ & $77.68 \pm 12.94^{\mathrm{b}}$ & $122.93 \pm 8.72^{\mathrm{a}}$ & $77.29 \pm 9.03^{b}$ & $80.63 \pm 7.45^{\mathrm{b}}$ \\
\hline $\mathrm{FSH}(\mathrm{mIU} / \mathrm{mL})$ & $4.51 \pm 0.08^{\mathrm{b}}$ & $4.74 \pm 0.06^{\mathrm{a}, \mathrm{b}}$ & $4.79 \pm 0.09^{\mathrm{a}}$ & $4.96 \pm 0.10^{\mathrm{a}}$ & $4.97 \pm 0.10^{\mathrm{a}}$ \\
\hline LH (mIU/mL) & $4.44 \pm 1.09^{\mathrm{a}}$ & $1.65 \pm 0.18^{\mathrm{b}}$ & $1.94 \pm 0.35^{\mathrm{b}}$ & $1.34 \pm 0.45^{\mathrm{b}}$ & $1.04 \pm 0.19^{\mathrm{b}}$ \\
\hline $\mathrm{P}_{4}(\mathrm{ng} / \mathrm{mL})$ & $17.98 \pm 5.46^{\mathrm{a}}$ & $3.51 \pm 0.81^{\mathrm{b}}$ & $8.54 \pm 2.15^{\mathrm{a}, \mathrm{b}}$ & $12.30 \pm 4.04^{\mathrm{a}, \mathrm{b}}$ & $4.80 \pm 1.41^{\mathrm{b}}$ \\
\hline \multicolumn{6}{|l|}{2 nd $d$ of estrus } \\
\hline GnRH (pg/mL) & $50.44 \pm 4.59^{\mathrm{a}}$ & $12.77 \pm 0.36^{\mathrm{c}}$ & $16.33 \pm 4.11^{\mathrm{b}, \mathrm{c}}$ & $40.73 \pm 16.46^{\mathrm{a}, \mathrm{b}}$ & $12.28 \pm 2.65^{\mathrm{c}}$ \\
\hline$E_{2}(p g / m L)$ & $109.13 \pm 11.07^{\mathrm{a}, \mathrm{b}}$ & $90.45 \pm 3.62^{\mathrm{b}}$ & $92.64 \pm 6.30^{\mathrm{b}}$ & $127.70 \pm 11.30^{\mathrm{a}}$ & $105.16 \pm 3.06^{\mathrm{a}, \mathrm{b}}$ \\
\hline $\mathrm{FSH}(\mathrm{mIU} / \mathrm{mL})$ & $1.38 \pm 0.04$ & $1.37 \pm 0.02$ & $1.38 \pm 0.03$ & $1.33 \pm 0.05$ & $1.45 \pm 0.07$ \\
\hline LH (mIU/ mL) & $5.87 \pm 0.48^{\mathrm{a}}$ & $3.29 \pm 0.52^{\mathrm{a}, \mathrm{b}}$ & $3.37 \pm 0.43^{\mathrm{a}, \mathrm{b}}$ & $4.91 \pm 1.50^{\mathrm{a}, \mathrm{b}}$ & $2.76 \pm 0.37^{\mathrm{b}}$ \\
\hline $\mathrm{P}_{4}(\mathrm{ng} / \mathrm{mL})$ & $25.40 \pm 3.12^{\mathrm{a}}$ & $7.99 \pm 1.14^{\mathrm{b}}$ & $18.55 \pm 0.83^{\mathrm{a}, \mathrm{b}}$ & $31.18 \pm 4.95^{\mathrm{a}}$ & $23.36 \pm 2.20^{\mathrm{a}}$ \\
\hline \multicolumn{6}{|l|}{ 4th day of estrus } \\
\hline GnRH (pg/mL) & $44.74 \pm 14.00^{\mathrm{a}}$ & $17.36 \pm 5.24^{\mathrm{a}, \mathrm{b}}$ & $10.09 \pm 3.42^{\mathrm{b}}$ & $45.17 \pm 13.98^{\mathrm{a}}$ & $12.70 \pm 2.97^{\mathrm{b}}$ \\
\hline $\mathrm{E}_{2}(\mathrm{pg} / \mathrm{mL})$ & $129.87 \pm 20.35$ & $112.28 \pm 34.05$ & $87.88 \pm 14.06$ & $159.70 \pm 23.37$ & $143.28 \pm 31.44$ \\
\hline FSH (mIU/mL) & $1.38 \pm 0.04$ & $1.32 \pm 0.01$ & $1.33 \pm 0.03$ & $1.35 \pm 0.05$ & $1.42 \pm 0.03$ \\
\hline $\mathrm{LH}(\mathrm{mIU} / \mathrm{mL})$ & $5.65 \pm 0.32^{\mathrm{a}}$ & $4.54 \pm 0.32^{\mathrm{a}, \mathrm{b}}$ & $2.25 \pm 0.37^{\mathrm{c}}$ & $3.40 \pm 0.55^{\mathrm{b}}$ & $3.45 \pm 0.28^{\mathrm{b}}$ \\
\hline $\mathrm{P}_{4}(\mathrm{ng} / \mathrm{mL})$ & $50.21 \pm 4.51^{\mathrm{a}}$ & $39.93 \pm 6.98^{\mathrm{a}, \mathrm{b}}$ & $28.76 \pm 4.05^{\mathrm{b}}$ & $37.75 \pm 5.22^{\mathrm{a}, \mathrm{b}}$ & $33.37 \pm 1.98^{\mathrm{b}}$ \\
\hline
\end{tabular}

SIF, soyabean isoflavones; EV, estradiol valerate; GnRH, gonadotrophin releasing hormone; $\mathrm{E}_{2}$, estrogen; FSH, follicle-stimulating hormone; LH, luteinizing hormone; $\mathrm{P}_{4}$, progesterone.

${ }^{a, b, c}$ Letters on the same row with different superscripts differs significantly $(\mathrm{p}<0.05)$.

on control (Figure 2). However, pigs on group SIF-500 showed similar GNRHR gene expression to the control group. Although, $F S H \beta$ gene expression for pigs exposed to SIF-1250 was similar to those on EV, FSH $\beta$ expression in the pituitary of pigs exposed to SIF-1250 was higher $(p<0.05)$ compared to control. The expression of LH $\beta$ didn't differ $(\mathrm{p}>0.05)$ in the pituitary of pigs exposed to SIF-250, SIF-500, and SIF-1250 compared to control. Pigs on EV however had reduced $(\mathrm{p}<0.05) L H \beta$ gene expression when compared to the control group.

\section{Steroid hormone gene and protein expression}

In the present study, the steroidogenic acute regulatory protein (StAR) and 3-beta-hydroxysteroid dehydrogenase/delta-5-delta-4 isomerase (3 $\beta$-HSD) expression in the ovary were significantly $(\mathrm{p}<0.05)$ down regulated following exposure to varying concentrations of SIF (250,
500, $1250 \mathrm{SIF}$ ) and EV as shown in Figure 3. Pigs on control and those on SIF-500 had similar expression of cytochrome P450 17A1 (CYP17A1) in the ovary with values higher $(p<0.05)$ than the rest treatment. The expression of cytochrome P450, family 11, subfamily A, polypeptide 1 (CYP11A1) in all the treatments was similar. The expression of cytochrome P450 19A1 (CYP19A1) in pigs exposed to SIF-250 and those on EV reduced $(\mathrm{p}<0.05)$ significantly when compared with control group.

The relative protein expression of StAR, 3 $\beta$-HSD, and CYP19 were detected by Western blot (Figure 4). The StAR protein expression was significantly $(\mathrm{p}<0.05)$ downregulated following exposure to varying concentrations of SIF and EV, while only $250 \mathrm{mg} / \mathrm{kg}$ of SIF decreased $(p<0.05)$ the relative protein expression of $3 \beta-H S D$. The relative expression of CYP19 was not affected $(\mathrm{p}>0.05)$.
KISS1

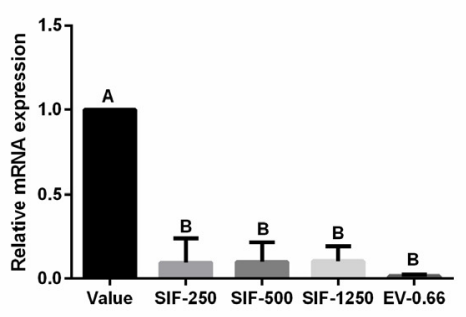

GPR54

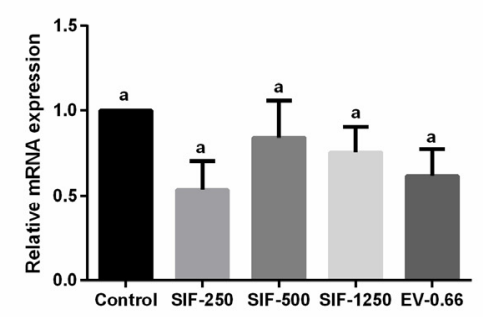

GNRH1

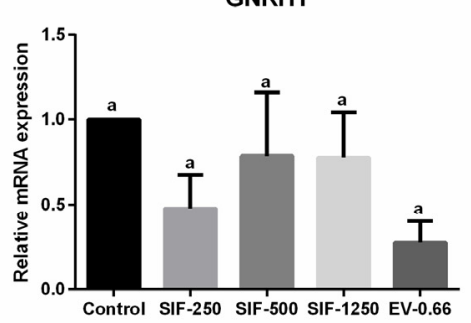

Figure 1. Effects of soyabean isoflavones (SIF) on the expression of genes in the hypothalamus of the mini-pigs. Pigs were exposed to varing dosages $(0,250,500$, and $1,250 \mathrm{mg} / \mathrm{kg})$ of SIF and estradiol valerate $(\mathrm{EV} ; 0.66 \mathrm{mg} / \mathrm{kg})$. The hypothalamus samples $(\mathrm{n}=6 \mathrm{per}$ treatment) from each pig was separated and frozen in liquid $\mathrm{N}$, and then stored at $-80^{\circ} \mathrm{C}$. Gene expression were analyzed by RT-PCR. Data were presented as mean \pm standard error of the mean. 
GNRHR

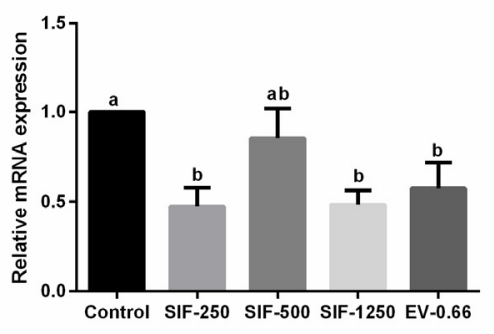

FSH-beta

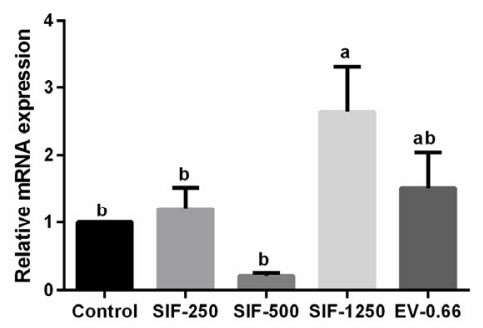

LH-beta

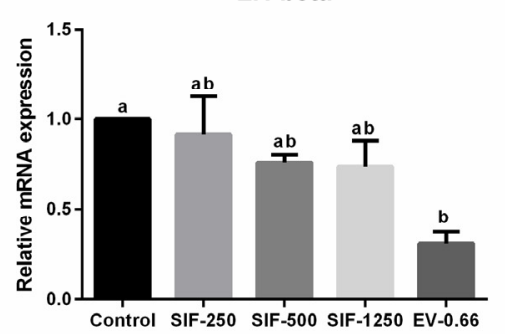

Figure 2. Effects of soyabean isoflavones (SIF) on the expression of genes in the pituitary of the mini-pigs. Pigs were exposed to varing dosages $(0,250,500$, and $1,250 \mathrm{mg} / \mathrm{kg})$ of SIF and estradiol valerate $(\mathrm{EV} ; 0.66 \mathrm{mg} / \mathrm{kg})$. The pituitary gland samples $(\mathrm{n}=6$ per treatment) from each pig was separated and frozen in liquid $\mathrm{N}$, and then stored at $-80^{\circ} \mathrm{C}$. Gene expression were analyzed by RT-PCR. Data were presented as mean \pm standard error of the mean.

\section{DISCUSSION}

It was observed from the current study that all pigs fed diet supplemented with SIF and EV showed delayed puberty. In fact most of them didn't reach puberty until 240 day of age. This was far beyond the normal pubertal age of this species. The delayed onset of puberty observed could be linked with the inclusion of estrogen-like chemicals used in this study (SIF). The mechanism underlining onset and attainments of puberty in pigs is linked to the production of oestrogen which is regulated by the circulating serum hormones. These hormones are generally regulated by the hypothalamic-pituitary-gonadal (HPG) axis. Endocrine disrupting chemicals (like SIF employed in this study) could affect HPG axis with various consequences on sexual development (Takeyoshi et al., 2002).

Long term exposure to SIF in the current study altered endogenous hormone concentration in the serum. Dietary supplementation with SIF reduced serum GnRH and $\mathrm{LH}$ concentration in 4 months old Bama miniature pigs while higher FSH concentration was also obtained with pigs fed increased SIF concentration (SIF-500 and SIF-1250) when compared to control. Serum concentration of $\mathrm{GnRH}, \mathrm{LH}$, and $\mathrm{P}_{4}$ were also altered in pigs at the second and fourth day of estrus following dietary supplementation with SIF. The trend of serum hormone concentration recorded in this study agreed with the findings of Wang et al. (2010) which reported that isoflavones and zearalenone inclusion could lead to increased FSH levels. Our previous works also showed reduced serum LH concentration following dietary
STAR

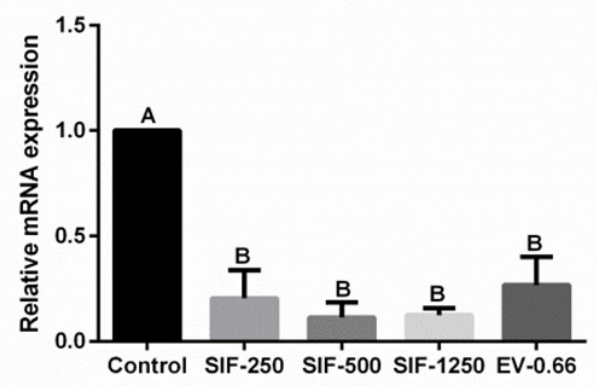

3beta HSD

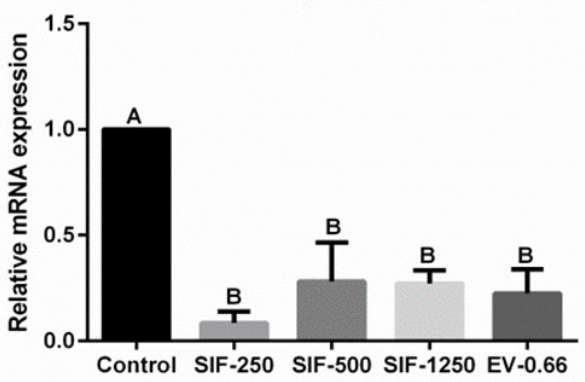

CYP11A1

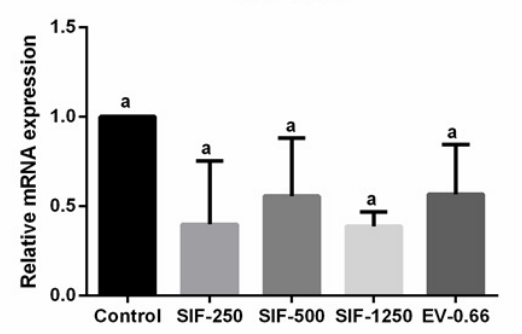

CYP17A1

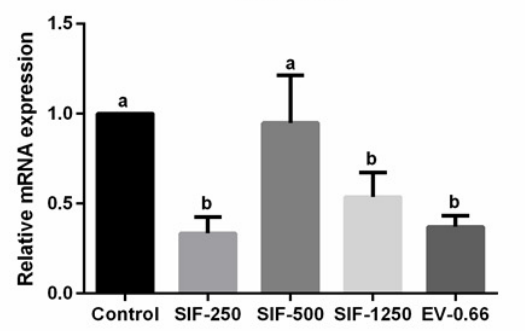

CYP19A1

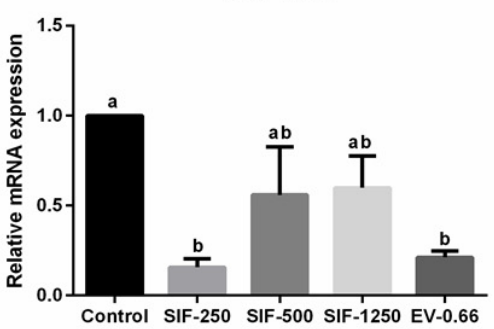

Figure 3. Effects of soyabean isoflavones (SIF) on the expression of steroid hormone genes in the ovary of the mini-pigs. Pigs were exposed to varing dosages $(0,250,500$, and $1,250 \mathrm{mg} / \mathrm{kg})$ of SIF and estradiol valerate (EV; $0.66 \mathrm{mg} / \mathrm{kg})$. The pigs were slaughtered and ovary samples ( $\mathrm{n}=6$ per treatment) were separated and frozen in liquid $\mathrm{N}$, and then stored at $-80^{\circ} \mathrm{C}$. Steroid hormone gene expression were analyzed by RT-PCR. Data were presented as mean \pm standard error of the mean. RT-PCR, real-time polymerase chain reaction. 


\section{StAR/ $\beta$-actin}

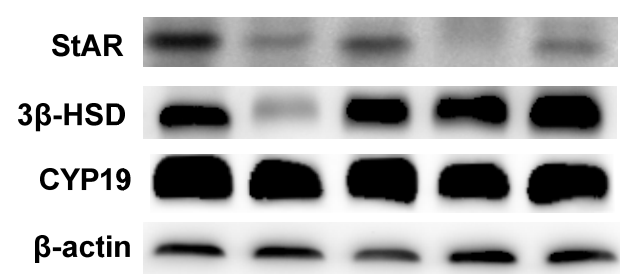

$3 \beta$-HSD/ $\beta$-actin

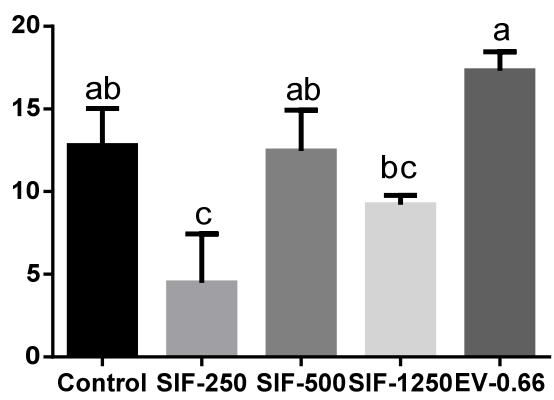

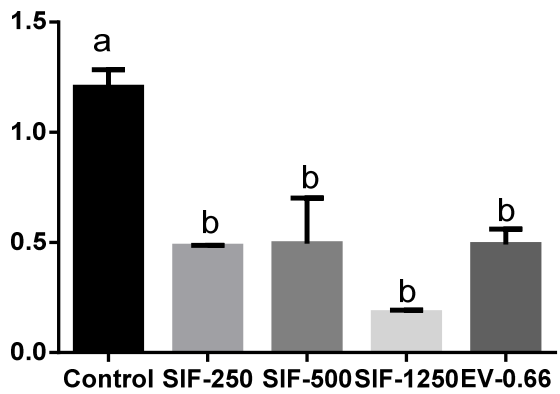

cyp19/ $\beta$-actin

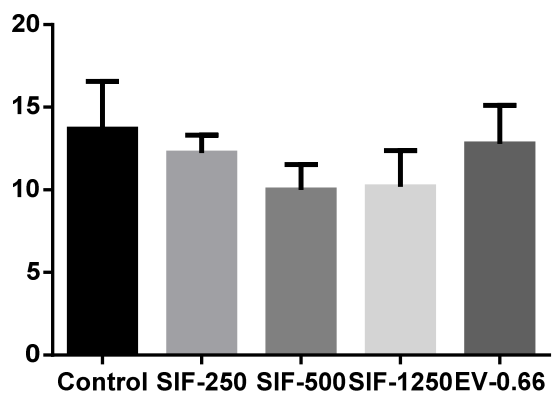

Figure 4. Effects of soyabean isoflavones (SIF) on the protein expression of steroid hormones in the ovary of the mini-pigs. Pigs were exposed to varing dosages $(0,250,500$, and $1,250 \mathrm{mg} / \mathrm{kg}$ ) of SIF and estradiol valerate $(\mathrm{EV} ; 0.66 \mathrm{mg} / \mathrm{kg})$. The pigs were slaughtered and ovary samples ( $\mathrm{n}=3$ per treatment) were separated and frozen in liquid $\mathrm{N}$, and then stored at $-80^{\circ} \mathrm{C}$. Steroid hormone protein expression were analyzed by Western blot. Data were presented as mean \pm standard error of the mean.

inclusion of $500 \mathrm{mg} / \mathrm{kg}$ soybean isoflavone in boars (Yuan et al., 2012). These indicated that puberty delay of female Bama miniature pigs induced by dietary supplementation with SIF may be due to the changes of these hormones. However, the current result was at variance with the findings of Ohno et al. (2003) who observed that administration of genistein to rats increased $\mathrm{LH}$ with no effect on FSH levels (Ohno et al., 2003). A month of soy ingestion was also reported to suppress $\mathrm{FSH}, \mathrm{LH}$ and increased follicular-phase estradiol concentrations (Cassidy et al., 1995; Lu et al., 1996). Differences between the finding in the current study and past literatures may be due to altered isoflavone metabolism (Persky et al., 1992), dosage, age of the animals, length of exposure and physiological condition of animal in question (Hwang et al., 2006).

A substantial body of work implicated kisspeptin neurons as primary mediators of gonadal steroid feedback control of $\mathrm{GnRH}$ release in mammals, because of the colocalization of kisspeptin cells with gonadal steroid receptors (Lehman et al., 2010), for example the colocalization of $\mathrm{ER} \alpha$ and $\mathrm{ER} \beta$ in kisspeptin neurons in rats and mice, both in ARC and AVPV of the hypothalamus. These indicates that kisspeptin neurons may be a point for the regulation of SIF reduced KISS1 gene expression in the hypothalamus of the pigs obtained in the current study following dietary supplementation with SIF agreed with Losa et al. (2011) who reported that high dose of Genistein induced lower numbers of KISS immunoreactive fibers in the AVPV and ARC (Losa et al., 2011). This trend shows that neonatal exposure to EDCs suppressed GnRH activity (in adulthood) and KISS fiber density in the AVPV (Bateman and Patisaul, 2008). However, GPR54 and GNRH1 were not affected in the present study. This implied that KISS1 in the hypothalamus may be the central point that regulates the synthesis, secretion of GnRH and the onset of puberty when SIF was supplemented to the pigs' diet.

The GnRH receptor is expressed specifically in pituitary gonadotropin (Thackray et al., 2010). Recent study found that intramuscular injection of $200 \mathrm{mg}$ or $400 \mathrm{mg}$ genistein did not change the expression of GNRHR of crossbred barrows (Clapper and Tomlin, 2012). However, reduced expression of GnRH receptor obtained in the current study with pigs fed with SIF-250 and SIF-1250 could be contributory to the delayed puberty observed. This is because GNRHR mediates the action of GnRH which regulate the release of $\mathrm{LH}$ (Ciechanowska et al., 2010). The present study found that serum LH level of the pigs was lower and FSH level was higher following dietary 
supplemented with SIF. LH and FSH composed with different $\beta$ subunits and synthesis of LH $\beta$ and FSH $\beta$ is the rate-limiting step for production of the mature hormones (Thackray et al., 2010). The present study found that dietary supplementation with SIF-1250 increase the expression of $\mathrm{FSH} \beta$, this is associated with the increase of serum FSH of the pigs. However, the expression of LH $\beta$ was decreased but didn't significantly differ, so the decrease of serum LH may be due to the down regulation of GNRHR in the pituitary of pigs fed basal diet with SIF.

The biosynthesis of steroid hormones is regulated mainly by the pituitary trophic hormones such as LH and FSH (Stocco, 2001). The present study found out that StAR and $3 \beta-H S D$ gene expression and StAR protein expression in the ovary of female Bama miniature pigs were decreased, suggesting that the synthesis of steroid hormones and follicular physical function were altered when SIF was fed. These genes played vital roles in the synthesis of steroid hormones in the ovary. During the production of testosterone, $3 \beta$-HSD catalyse the conversion of pregnenolone to $\mathrm{P}_{4}$ (Tiemann et al., 2007). The downregulation of StAR may due to the fact that the StAR is always up-regulated by LH (Edson et al., 2009) since circulating $\mathrm{LH}$ reduced in the treatment groups. The expression of CYP11A1 and CYP17A1 was not influenced by dietary SIF treatments. CYP19 (aromatase) catalyses the final rate-limiting reaction in the several steps where estrogen is synthesised (Wang et al., 2008), and they found that the mRNA abundance of aromatase was reduced by biochanin A (another kind of isoflavones) when using the SK-BR-3 cells as a model. We found that the gene expression of CYP19A1 was decreased in groups fed diet containing $250 \mathrm{mg} / \mathrm{kg} \mathrm{SIF}$ and $0.66 \mathrm{mg} / \mathrm{kg} \mathrm{EV}$ but the protein expression of CYP19 was not affected. This may be the reason that the serum $E_{2}$ level didn't differ among treatments in the present study.

$\mathrm{E}_{2}$ and $\mathrm{P}_{4}$ regulate $\mathrm{FSH}$ and $\mathrm{LH}$ secretion by negative and positive feedback to the hypothalamus and the anterior pituitary (Thackray et al., 2010), and the proper functioning of HPG axis and maintenance of a normal ratio of LH/FSH is essential for reproductive health. Serum $E_{2}$ level of female Bama miniature pigs didn't change after dietary supplementation of SIF, but the $\mathrm{P}_{4}$ level decreased. This may be associated with the decrease of serum GnRH and LH level which in turn induce puberty delay of the pigs.

\section{IMPLICATIONS}

The striking ability of SIF to induce puberty delay in Bama miniature pigs when included in their feed at various $(250,500$, and $1,250 \mathrm{mg} / \mathrm{kg})$ dosage happens to be the primary findings of this study. This delay in the onset of puberty following SIF inclusion could be attributed to the reduced serum GnRH and LH concentration, suppressing effect on the gene expression of KISS1 (in the hypothalamus), GNRHR gene expression (in the pituitary), down regulating effect on StAR and $3 \beta$-HSD expression (in the ovary) resulting in altered synthesis of steroid hormones in growing Bama miniature pigs.

\section{CONFLICT OF INTEREST}

We certify that there is no conflict of interest with any financial organization regarding the material discussed in the manuscript.

\section{ACKNOWLEDGMENTS}

This research was supported by the National Natural Science Foundation of China (No. 31272462, No. 30972118, and No. 31301985) and Scientific Research Fund of Hunan Provincial Education Department Project (12B058).

\section{REFERENCES}

Bateman, H. L. and H. B. Patisaul. 2008. Disrupted female reproductive physiology following neonatal exposure to phytoestrogens or estrogen specific ligands is associated with decreased gnrh activation and kisspeptin fiber density in the hypothalamus. Neurotoxicology 29:988-997.

Cassidy, A., S. Bingham, and K. Setchell. 1995. Biological effects of isoflavones in young women: Importance of the chemical composition of soyabean products. Br. J. Nutr. 74:587-601.

Ciechanowska, M., M. Lapot, K. Mateusiak, and F. Przekop. 2010. Neuroendocrine regulation of gnrh release and expression of gnrh and gnrh receptor genes in the hypothalamus-pituitary unit in different physiological states. Reprod. Biol. 10:85-124.

Clapper, J. and A. Tomlin. 2012. Effects of the phytoestrogen genistein on the porcine anterior pituitary insulin-like growth factor system. Domest. Anim. Endocrinol. 42:173-182.

Dickerson, S. M. and A. C. Gore. 2007. Estrogenic environmental endocrine-disrupting chemical effects on reproductive neuroendocrine function and dysfunction across the life cycle. Rev. Endocr. Metab. Disord. 8:143-159.

Doerge, D. R. and D. M. Sheehan. 2002. Goitrogenic and estrogenic activity of soy isoflavones. Environ. Health Perspect. 110(Suppl. 3):349-353.

Edson, M. A., A. K. Nagaraja, and M. M. Matzuk. 2009. The mammalian ovary from genesis to revelation. Endocr. Rev. 30:624-712.

Fu, W. J., J. Hu, T. Spencer, R. Carroll, and G. Wu. 2006. Statistical models in assessing fold change of gene expression in real-time RT-PCR experiments. Comput. Biol. Chem. 30:2126.

Hwang, C. S., H. S. Kwak, H. J. Lim, S. H. Lee, Y. S. Kang, T. B. Choe, H. G. Hur, and K. O. Han. 2006. Isoflavone metabolites and their in vitro dual functions: They can act as an estrogenic agonist or antagonist depending on the estrogen concentration. J. Steroid Biochem. Mol. Biol. 101:246-253.

Jefferson, W. N., E. Padilla-Banks, and R. R. Newbold. 2005. 
Adverse effects on female development and reproduction in cd-1 mice following neonatal exposure to the phytoestrogen genistein at environmentally relevant doses. Biol. Reprod. 73:798-806.

Jefferson, W. N. and C. J. Williams. 2011. Circulating levels of genistein in the neonate, apart from dose and route, predict future adverse female reproductive outcomes. Reprod. Toxicol. 31:272-279.

Ju, X. H., H. J. Xu, Y. H. Yong, L. L. An, Y. M. Xu, P. R. Jiao, and M. Liao. 2014. Heat stress upregulates the expression of TLR4 and its alternative splicing variant in bama miniature pigs. J. Integr. Agric. 13:2479-2487.

Lehman, M. N., C. M. Merkley, L. M. Coolen, and R. L. Goodman. 2010. Anatomy of the kisspeptin neural network in mammals. Brain Res. 1364:90-102.

Li, D. F., J. L. Nelssen, P. G. Reddy, F. Blecha, R. Klemm, and R. D. Goodband. 1991. Interrelationship between hypersensitivity to soybean proteins and growth performance in early-weaned pigs. J. Anim. Sci. 69:4062-4069.

Losa, S. M., K. L. Todd, A. W. Sullivan, J. Cao, J. A. Mickens, and H. B. Patisaul. 2011. Neonatal exposure to genistein adversely impacts the ontogeny of hypothalamic kisspeptin signaling pathways and ovarian development in the peripubertal female rat. Reprod. Toxicol. 31:280-289.

Lu, S. S., C. P. Lau, Y. F. Tung, S. W. Huang, Y. H. Chen, H. C. Shih, S. C. Tsai, C. C. Lu, S. W. Wang, J. J. Chen, E. J. Chien, C. H. Chien, and P. S. Wang. 1996. Lactate stimulates progesterone secretion via an increase in cAMP production in exercised female rats. Am. J. Physiol. 271:E910-915.

Nahoko I., U. Yoshihisa, T. Yoko, N. Tomoko, K. Masatoshi, N. Yousuke, W. Youki, M. Shiori, T. Junko, I. Naoko, M. Fuko, O. Satoshi, M. Kei-ichiro, T. Hiroko. 2014. KISS1 gene expression in the developing brain of female pigs in pre- and peripubertal periods. J. Reprod. Dev. 60:312-316.

Oakley, A. E., D. K. Clifton, and R. A. Steiner. 2009. Kisspeptin signaling in the brain. Endocr. Rev. 30:713-743.

Ohno, S., Y. Nakajima, K. Inoue, H. Nakazawa, and S. Nakajin. 2003. Genistein administration decreases serum corticosterone and testosterone levels in rats. Life Sci. 74:733-742.

Persky, V. W., R. T. Chatterton, L. V. Van Horn, M. D. Grant, P. Langenberg, and J. Marvin. 1992. Hormone levels in vegetarian and nonvegetarian teenage girls: Potential implications for breast cancer risk. Cancer Res. 52:578-583.

Setchell, K. D., L. Zimmer-Nechemias, J. Cai, and J. E. Heubi. 1998. Isoflavone content of infant formulas and the metabolic fate of these phytoestrogens in early life. Am. J. Clin. Nutr. 68:1453s-1461s.

Soede, N. M., P. Langendijk, and B. Kemp. 2011. Reproductive cycles in pigs. Anim. Reprod. Sci. 124:251-258.
Sterle, J. A. and W. R. Lamberson. 1996. Effects of exposure to an estrual female on attainment of puberty in gilts. Theriogenology 45:733-744.

Stocco, D. M. 2001. StAR protein and the regulation of steroid hormone biosynthesis. Annu. Rev. Physiol. 63:193-213.

Strom, B. L., R. Schinnar, E. E. Ziegler, K. T. Barnhart, M. D. Sammel, G. A. Macones, V. A. Stallings, J. M. Drulis, S. E. Nelson, and S. A. Hanson. 2001. Exposure to soy-based formula in infancy and endocrinological and reproductive outcomes in young adulthood. Jama 286:807-814.

Takeyoshi, M., M. Sawaki, S. Noda, T. Muroi, and K. Yamasaki. 2002. Effect of gonadotropin-releasing hormone antagonist on ovarian and uterine weights in immature female rats. Reprod. Toxicol. 16:367-369.

Thackray, V. G., P. L. Mellon, and D. Coss. 2010. Hormones in synergy: Regulation of the pituitary gonadotropin genes. Mol. Cell. Endocrinol. 314:192-203.

Tiemann, U., F. Schneider, J. Vanselow, and W. Tomek. 2007. In vitro exposure of porcine granulosa cells to the phytoestrogens genistein and daidzein: Effects on the biosynthesis of reproductive steroid hormones. Reprod. Toxicol. 24:317-325.

Tomikawa, J., T. Homma, S. Tajima, T. Shibata, Y. Inamoto, K. Takase, N. Inoue, S. Ohkura, Y. Uenoyama, K. Maeda, and H. Tsukamura. 2010. Molecular characterization and estrogen regulation of hypothalamic KISSI gene in the pig. Biol. Reprod. 82:313-319.

Wang, D. F., N. Y. Zhang, Y. Z. Peng, and D. S. Qi. 2010. Interaction of zearalenone and soybean isoflavone on the development of reproductive organs, reproductive hormones and estrogen receptor expression in prepubertal gilts. Anim. Reprod. Sci. 122:317-323.

Wang, Y., W. Man Gho, F. L. Chan, S. Chen, and L. K. Leung. 2008. The red clover (Trifolium pratense) isoflavone biochanin A inhibits aromatase activity and expression. Br. J. Nutr. 99:303-310.

Yan, G. R., C. L. Xiao, G. W. He, X. F. Yin, N. P. Chen, Y. Cao, and Q. Y. He. 2010. Global phosphoproteomic effects of natural tyrosine kinase inhibitor, genistein, on signaling pathways. Proteomics 10:976-986.

Yin, Y. L., Z. Y. Deng, H. L. Huang, T. J. Li, and H. Y. Zhong. 2004. The effect of arabinoxylanase and protease supplementation on nutritional value of diets containing wheat bran or rice bran in growing pig. J. Anim. Feed Sci. 13:445461.

Yuan, X. X., B. Zhang, L. L. Li, C. W. Xiao, J. X. Fan, M. M. Geng, and Y. L. Yin. 2012. Effects of soybean isoflavones on reproductive parameters in Chinese mini-pig boars. J. Anim. Sci. Biotechnol. 3:31. 